удк:338.48(477.42)

DOI https://doi.org/10.32851/2708-0366/2021.7.16

Тищенко С.В.

кандидат економічних наук, доцент, Поліський національний університет ORCID: https://orcid.org/0000-0001-5650-5575

Tyshchenko Svitlana

Polissia National University

\title{
ЦИФРОВІ ТЕХНОЛОГІЇ В ІНДУСТРІЇ ГОСТИННОСТІ
}

\section{DIGITAL TECHNOLOGIES IN THE HOSPITALITY INDUSTRY}

\begin{abstract}
Проаналізовано тенденції розвитку та використання цฺифрових технологій в індустрії гостинності. Зазначено, що індустрія гостинності - одна з найбільш перспективних галузей глобальної економіки. Досліджено сучасний стан розвитку та функиіонування малого та середнього бізнесу та показано його особливу роль в індустрії гостинності. Здійснено аналіз структурного розподілу підприємств індустрії гостинності та виявлено тендениії щодо їх розвитку. Проаналізовано потенціал цифрровізації найвідоміших компаній, які відіграють найважливішу роль у функиіонуванні індустрії гостинності, що самі починали як стартапи. Досліджено чинники, які стримують розвиток иифрових технологій, та їх значення для малого та середнього підприємництва. Розроблено авторський підхід до визначення ключових технологічних можливостей иифровізації для малого та середнього бізнесу індустрії гостинності.
\end{abstract}

Ключові слова: иифрові технології, індустрія гостинності, малий та середній бізнес, блокчейн, голосові технології, роботизація, штучний інтелект.

Отмечено, что индустрия гостеприимства - одна из наиболее перспективных отраслей глобальной экономики. Исследовано современное состояние развития и функиионирования малого и среднего бизнеса и показана его особая роль в индустрии гостеприимства. Осуществлен анализ структурного распределения предприятий индустрии гостеприимства и выявлены тенденции их развития. Проанализирован потенциал илифровизации самых известных компаний, которые играют важснейшую роль в функиионировании индустрии гостеприилства и сами начинали как стартапь. Исследованы факторы, сдерживающие развитие иифровых технологий, и их значение для малого и среднего предпринимательства. Разработан авторский подход к определению ключевых технологических возможностей ичифровизации для малого и среднего бизнеса индустрии гостеприимства.

Ключевые слова: ичифровые технологии, индустрия гостеприимства, мальй и средний бизнес, блокчейн, голосовые технологии, роботизация, искусственный интеллект.

Trends in the development and use of digital technologies in the hospitality industry are analyzed. The global nature of technological integration leads to a gradual change in the business process. Today's trend is a digital transformation that affects all areas of activity focused on the global application of digital technologies in the activities of economic entities, the formation of the information society and the digital economy as a whole, ie the use of technological opportunities. It is noted that the hospitality industry is one of the most promising sectors of the global economy. The digital economy is considered to be the economy directly related to the processes of development and implementation of digital computer technologies in all spheres of economic production and consumption. The digital economy is characterized by the transition from the third industrial revolution to the fourth industrial revolution. It covers the area of online services and goods, namely e-payment services and e-commerce, e-commerce and e-commerce, crowdfunding, e-banking and more. The current state of development and functioning of small and medium business is studied and its special role in the hospitality industry is shown. The analysis of the structural distribution of the enterprises of the hospitality industry is carried out and the tendencies concerning their development are revealed. The potential of digitalization of the most famous companies that play a crucial role in the functioning of the hospitality industry, which started as startups, is analyzed. An author's approach to identifying key technological 
opportunities for digitalization for small and medium-sized businesses in the hospitality industry block chain, modeling and forecasting, horizontal and vertical integration, Internet of Things, cloud computing and data storage, cybersecurity, augmented reality, voice technology, artificial intelligence). The factors restraining the development of digital technologies and their importance for small and medium enterprises (financial and economic, regulatory, legal instability, lack of investment in high-tech industries, low living standards, digital illiteracy).

Key words: digital technologies, hospitality industry, small and medium business, block chain, voice technologies, robotics, artificial intelligence.

Постановка проблеми. У сучасних умовах ключовим чинником розвитку економіки XXI ст. є дані, представлені у цифровій формі. У зв'язку із цим IT-технологіям відводиться першочергова роль. Стрімкий розвиток цифрової економіки у світі забезпечує підвищення конкурентоспроможності майже в усіх секторах економіки, відповідно, і суб'єктів господарювання. Глобальний характер технологічної інтеграції призводить до поступової зміни процесу ведення бізнесу. Тренд сьогоднішнього часу - цифрова трансформація, що торкається усіх сфер діяльності й орієнтована на глобальне застосування цифрових технологій у діяльності економічних суб'єктів, формування інформаційного суспільства та цифрової економіки у цілому, тобто застосування технологічних можливостей.

Аналіз останніх досліджень і публікацій. Дослідженню питань щодо розвитку індустрії гостинності та застосування в ній цифрових технологій присвячено багато праць вітчизняних та закордонних учених, таких як: В.А. Алеєва, Ю.Д. Мочалова, А. Андрєєв, Е.З. Герчикова, Е.П. Спиридонова, Н.Ф. Данилова, І.В. Сараєва, А.А. Клейман, О.А. Бабанчикова, Н.Б. Кущевий, М.А. Іванова, М.А. Морозов, Н.С. Морозова, М.А. Пивоварова, М. Шерстньова, N. Negroponte.

Формулювання цілей статті. Метою статті $є$ дослідження процесу формування та використання цифрових технологічних можливостей в індустрії гостинності. Вирішено такі завдання: 1. Визначено, що цифрова революція відіграє важливу роль у зміцненні позицій малого та середнього бізнесу в індустрії гостинності. 2. Досліджено чинники, що стримують розвиток цифрових технологій в індустрії гостинності. 3. Розглянуто сучасний стан розвитку та застосування цифровізації в індустрії гостинності України. 4. Здійснено класифікацію ключових технологічних можливостей цифровізації для малого та середнього бізнесу індустрії гостинності. Під час написання статті використовувалися теоретичні та емпіричні методи дослідження, такі як: класифікація та систематизація наукових досліджень, теоретичний аналіз, узагальнення тощо.

Виклад основного матеріалу. В останньому десятилітті проблеми впровадження цифрових технологій знайшли широкого висвітлення. Автором цього напряму став у 1995 р. професор Масачуссетського інституту технологій Н. Негропонте [3; 7; 15]. Основа його дослідження - це протиставлення традиційної та цифрової економіки за інтенсивного розвитку інформаційно-комунікаційних технологій.

Для цифрової економіки характерним є перехід від Третьої промислової революції до Четвертої індустріальної революції. «Цифрова економіка» відображає радикальні зміни другої половини ХХ ст., які стали можливими в результаті розвитку цифрових обчислювальних і комунікаційних технологій.

Під цифровою економікою розуміють економіку, безпосередньо пов'язану з процесами розвитку й упровадження цифрових комп'ютерних технологій у всі сфери економічного виробництва і споживання. Як правило, вона охоплює сферу надання онлайн-послуг і товарів, а саме сервіси електронних платежів і електронну комерцію, Інтернет-торгівлю й Інтернет речей (IOT - Internet of Things), краудфандінг, Інтернет-банкінг та ін. Серед новітніх цифрових технологій, які виступають платформою цифровізації і цифрової економіки, виділяють технології Big Data, розвиток хмарних 
сервісів і штучного інтелекту (нейромережі), розумних технологій і технологій визначення місцезнаходження, Інтернет речей, а також промисловий Інтернет речей (IIT Industrial Internet of Things), 3D-друк [14].

Цифровизація і доступність інфраструктури забезпечують повноцінну взаємодію учасників економічної діяльності. Як відмінні особливості цифрової економіки необхідно відзначити наявність персоніфікованих сервісних моделей, а також розвиток економіки спільного споживання і sharing-сервісів.

Особливо актуальні процеси цифровізації для сфери обслуговування. Торгові та транспортні компанії, підприємства індустрії гостинності, громадського харчування отримали можливість розширити цільову аудиторію, поліпшити якість обслуговування, розвиватися прискореними темпами, приймаючи до уваги, що в глобальній цифровій економіці перемога буде за тими, у чиєму арсеналі буде задіяна велика кількість якісних цифрових платформ.

Індустрія гостинності об'єднує усі галузі економіки всіх рівнів, пов'язані з обслуговуванням та сервісом (туристів, відвідувачів, місцевих та регіональних жителів) за допомогою підприємницького сектору спеціалізованого та інфраструктурного значення, базуючись на принципі гостинності, що виступає їх спільним знаменником (складено автором) [12].

Під терміном «Індустрія гостинності» також розуміють різні форми господарювання, наприклад готелі, розважальні заклади, харчування (кафе та ресторани), транспортні послуги, Інтернет, пошта, банки тощо. Із загальної кількості суб'єктів господарювання за видами економічної діяльності можна зазначити переважання господарств малого підприємництва та мікропідприємців (рис. 1).

Зростання відбулося для суб' єктів малого підприємництва на 2\%, або на 7932 господарства, та суб'єктів мікропідприємництва - на 4,2\%, або на 41,26 од. Якщо розглядати в розрізі видів діяльності, то слід зазначити, що така тенденція спостерігається й у підприємствах індустрії гостинності (рис. 1).

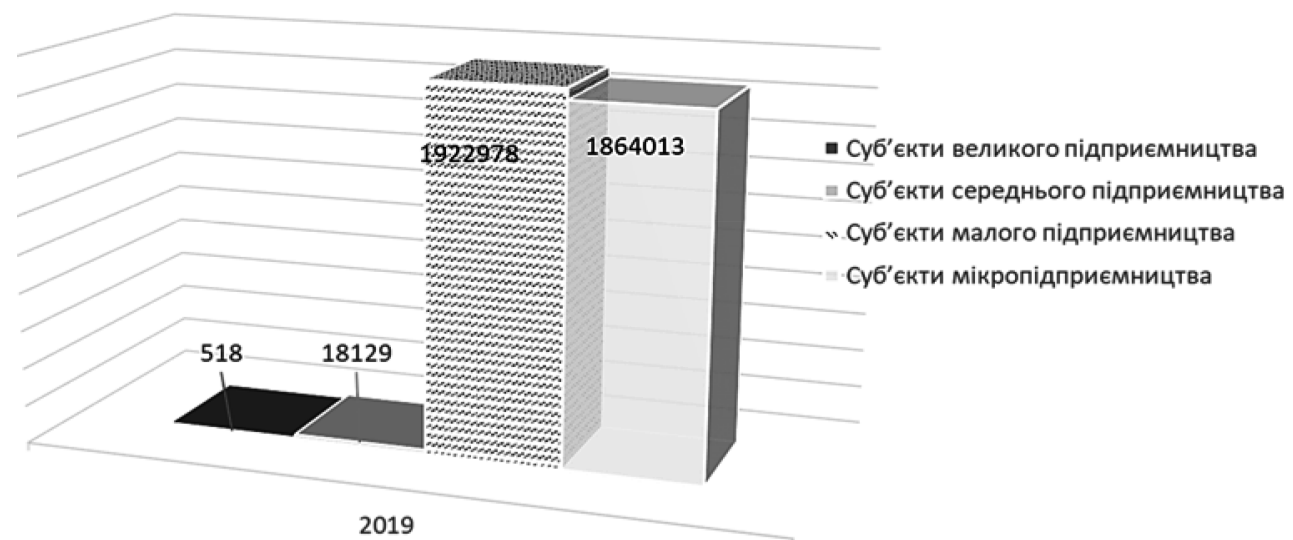

Рис. 1. Структурний розподіл підприємств індустрії гостинності у 2019 р.

Відіграючи важливу роль в економіці країни, малий та середній бізнес в індустрії гостинності відчуває нині цілу низку негативних тенденцій, викликаних, головним чином, ситуацією з COVID-19, впливом політичних і економічних санкцій із боку країн Заходу. Окрім того, стримує розвиток малого підприємництва значна кількість внутрішніх чининків, серед яких - невизначеність економічної ситуації в країні, брак власних фінансових коштів, високий відсоток комерційного кредиту тощо. 
Таблиця 1

Кількість підприсмств та фізичних осіб - підприсмців

за їх розмірами за видами економічної діяльності в Україні за 2014-2019 рр.

\begin{tabular}{|c|c|c|c|c|c|c|c|}
\hline & & \multicolumn{3}{|c|}{$\begin{array}{l}\text { Суб'єкти малого } \\
\text { підприсмництва }\end{array}$} & \multicolumn{3}{|c|}{ Суб'єкти мікропідприсмництва } \\
\hline $\begin{array}{c}\text { Вид } \\
\text { діяльності }\end{array}$ & роки & усього & $\begin{array}{l}\text { підпри- } \\
\text { ємства }\end{array}$ & $\begin{array}{c}\text { фізичні } \\
\text { особи } \\
\text { підприсмці }\end{array}$ & усього & $\begin{array}{c}\text { підпри- } \\
\text { смства }\end{array}$ & $\begin{array}{c}\text { фізичні особи } \\
\text { підприсмці }\end{array}$ \\
\hline $\begin{array}{l}\text { Тимчасове } \\
\text { розміщування } \\
\text { й організація } \\
\text { харчування }\end{array}$ & $\begin{array}{l}2014 \\
2015 \\
2016 \\
2017 \\
2018 \\
2019\end{array}$ & $\begin{array}{l}49593 \\
57248 \\
58169 \\
57431 \\
57300 \\
61466 \\
69382\end{array}$ & $\begin{array}{l}9353 \\
7593 \\
7453 \\
6300 \\
7022 \\
7272 \\
7611\end{array}$ & $\begin{array}{l}40240 \\
49240 \\
50716 \\
51131 \\
50278 \\
54194 \\
61771\end{array}$ & $\begin{array}{l}46456 \\
55381 \\
56665 \\
55629 \\
55106 \\
58378 \\
66435\end{array}$ & $\begin{array}{l}7440 \\
6342 \\
6272 \\
5116 \\
5806 \\
6014 \\
6303\end{array}$ & $\begin{array}{c}3906 \\
49039 \\
50393 \\
50513 \\
49300 \\
52364 \\
60132\end{array}$ \\
\hline $\begin{array}{l}\text { Мистецтво, } \\
\text { спорт, розваги } \\
\text { та відпочинок }\end{array}$ & $\begin{array}{l}2010 \\
2014 \\
2015 \\
2016 \\
2017 \\
2018 \\
2019\end{array}$ & $\begin{array}{l}11742 \\
13424 \\
14756 \\
13757 \\
12934 \\
13691 \\
15064\end{array}$ & $\begin{array}{l}1969 \\
1847 \\
1963 \\
1591 \\
1816 \\
2031 \\
2248\end{array}$ & $\begin{array}{c}9771 \\
11577 \\
12793 \\
12166 \\
11118 \\
11660 \\
12816\end{array}$ & $\begin{array}{l}11439 \\
13136 \\
14479 \\
13424 \\
12556 \\
13204 \\
14581\end{array}$ & $\begin{array}{l}1719 \\
1627 \\
1716 \\
1328 \\
1545 \\
1720 \\
1910\end{array}$ & $\begin{array}{c}9720 \\
11509 \\
12763 \\
12096 \\
11011 \\
11484 \\
12671\end{array}$ \\
\hline $\begin{array}{l}\text { Надання } \\
\text { інших видів } \\
\text { послуг }\end{array}$ & $\begin{array}{l}2010 \\
2014 \\
2015 \\
2016 \\
2017 \\
2018 \\
2019\end{array}$ & $\begin{array}{c}128117 \\
86664 \\
89855 \\
86097 \\
100548 \\
109295 \\
114173\end{array}$ & $\begin{array}{l}4566 \\
3952 \\
3845 \\
3204 \\
3376 \\
3321 \\
3387\end{array}$ & $\begin{array}{c}123550 \\
82712 \\
86010 \\
82893 \\
97172 \\
105974 \\
110786\end{array}$ & $\begin{array}{c}126731 \\
86019 \\
89332 \\
85574 \\
100066 \\
108774 \\
113656\end{array}$ & $\begin{array}{l}3689 \\
3440 \\
3383 \\
2792 \\
3015 \\
2998 \\
3059\end{array}$ & $\begin{array}{c}123042 \\
82579 \\
85949 \\
82782 \\
9705 \\
105776 \\
110597\end{array}$ \\
\hline
\end{tabular}

У всьому світі невеликі готелі, сімейні кафе та ресторани - ключовий елемент індустрії гостинності, що формує привабливість регіонів, забезпечуючи гостям безпосередній контакт із неповторною національною культурою. Індустрія гостинності - одна 3 найбільш перспективних галузей глобальної економіки. Швидкий розвиток індустрії гостинності зміцнюється за рахунок глобалізації ринку праці, росту мобільності підприємців, світової конкуренції у сфері інновацій в підприємництві, сфери, орієнтованої на глобальне приєднанні цифрових технологій.

Цифрова революція вже відіграла дуже важливу роль у зміцненні позицій малого та середнього бізнесу в індустрії гостинності. Зазначимо, що компанії, які відіграють найважливішу роль у цьому питанні, самі починали як стартапи:

- Booking.com - гостинний агрегатор дав можливість потенційним клієнтам ознайомитися з невеликими гостьовими домами з усього світу, що забезпечив їй найширший доступ до клієнтської бази;

- $A i r B \& B$ - повторний успіх Booking.com, сформував новий ринок оренди апартаментів;

- багаточисельні агрегатори таксі - Uber, Gett та їхні клони залучили в малий бізнес величезну кількість людей, давши їм можливість заробляти на своєму авто, i водночас зробили послуги таксі доступнішими.

Сучасний ринок гостинного господарства неможливо уявити без виняткового внеску цих компаній. Потенціал цифровізації для розвитку малого та середнього бізнесу ще далеко не вичерпний. Можна виділити кілька ключових технологічних можливостей: 


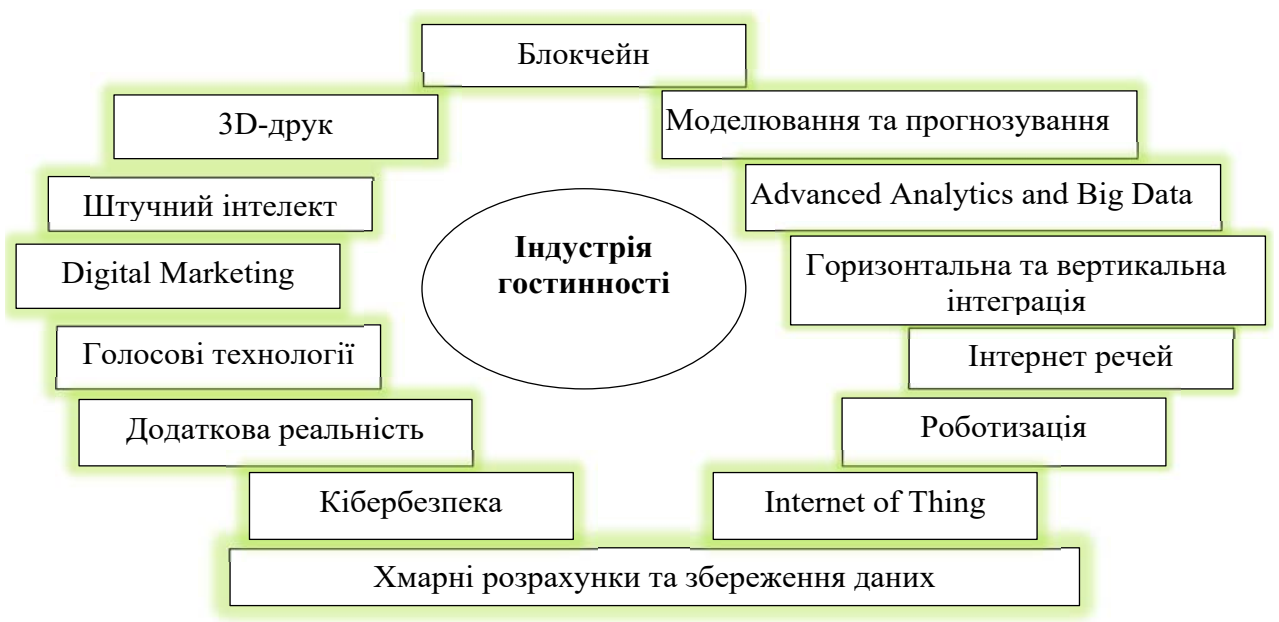

Рис. 2. Ключові технологічні можливості иฺифровізації

для малого та середнього бізнесу індустрії гостинності

Штучний інтелект. Передусім може забезпечити максимальний персоналізований результат під час планування подорожей. Опираючись на інформацію про вподобання клієнтів, пропонуючи рішення, що використовуються іншими подорожуючими, AC-системи можуть значно поліпшити та спростити організацію відпустки або подорожі, допомогти зекономити ресурси.

Інтернет речей. У перспективі $є$ ключовим елементом сервісу, що забезпечує «безшовні» подорожі: переліт, трансфер, готель, заказ машини, заказ їжі тощо. Обмінюючись даними пристроями, зазначені технології можуть скоротити до мінімуму будь-які очікування, усунути багато проблем - від відсутності місця на парковці до втрати орієнтиру в чужому місці.

Роботизація. Технології коботів - роботів, що вміють розуміти та робити з людьми, поступово стають усе більш реальними. Роботи-прибиральники вже $є$ реальністю і суттєво спрощують блок праці. Скорочуючи необхідність у праці персоналу, така техніка може істотно спростити, наприклад, ведення сімейного готельного бізнесу.

Голосові технологіï. Ефективне розпізнання голосових повідомлень дає можливість оптимізувати багато процесів. Завдяки їм навіть невеликий сімейний готель може забезпечити клієнтами цілодобовий сервіс.

Блокчейн. Ця технологія, формуючи «довірене цифрове середовище», дає змогу значно підвищити надійність заказів, бронювань та платежів. Забезпечить надійність інформації та відгуків про послуги.

На світовій арені Тайвань є однією з найбільш країн Південно-Східної Азії, важливим учасником глобальної галузі високих технологій, що спеціалізується на галузях електронної промисловості. Виробник комп'ютерної техніки та компонентів ASUS - компанія тайванського походження. Для мобільності накопиченого потенціалу та посилення державних конкурентних переваг у сфері інноваційного підприємництва в 2018 р. в країні була створена Тайванська технічна арена - Taiwan Tech Arena (TTA). Це флагманська програма розвитку екосистем стартапів, створена Міністерством наук та технологій. Головна особливість програми - виділення кількох ключових «вертикалей» у термінових програмах, у яких створено основні конкурентні переваги, якість таких вертикальних версій: продукція електронної промисловості та Інтернет, охорона здоров'я та харчові технології. Сьогодні, згідно з даними звіту «Тайванський звіт про екосистему запуску», у рамках програми Taiwan Tech Arena підтримку отри- 
мали майже 400 тайванських та міжнародних стартапів. Важливо також підкреслити, що екосистема стартапів Тайваня має ярко виражену експортну спрямованість [6].

До чинників, що стримують розвиток цифрових технологій в індустрії гостинності, слід віднести:

- ф фінансово-економічні (середньому та малому бізнесу сфери гостинності досить складно вкладати значні кошти у цифровізацію діяльності, а пільги та програми щодо їх підтримки та стимулювання у цьому напрямі не передбачені);

- нормативно-правові (відсутність чіткого нормативно-правового законодавства, що регламентуватиме взаємодію суб'єктів під час переходу у цифровий простір, у тому числі захист персональних даних, контроль достовірності акаунтів і наданої інформації);

- загальна нестабільність (відмінності у фінансових і політичних можливостях регіонів для інтеграції у цифровий простір країни);

- дефіцит інвестицій у високотехнологічні галузі, вплив санкцій, перш за все обмежений доступ до трансферу технологій та імпорту готових рішень);

- низький рівень життя населення країни (відсутність можливості придбання сучасних максимально функціональних гаджетів, використання платного контенту i роумінгових послуг Інтернету в подорожах);

- цифрова безграмотність населення (велика частина населення не знає про можливості цифрових технологій або знає дуже поверхнево).

Існує низка чинників, що підтримують розвиток даної галузі і процесів цифровізації:

- ізоляція від трансферу технологій, що вимагає від бізнесу застосування саме українських розробок;

- ефект «низької бази», здатний різко оптимізувати бізнес-процеси за рахунок модернізації й упровадження інформаційних технологій;

- перспективи зміни бізнес-моделей, що зумовлюють створення нових послуг.

Індустрія гостинності постійно, а в останній час наростаючими темпами, починає максимально використовувати технологічні можливості. Найбільш цікавою зараз $є$ технологія аналізу відгуків через пропозицію, які клієнти готелів надають після відвідування готелю, водночас можуть бути основою для замовлення майбутніх номерів. Сьогодні 70\% користувачів підбирають готелі на основі відгуків і оцінок. Так, провідні Інтернет-портали проводять ретельний аналіз і моніторинг переваг користувача і забезпечують його корисною інформацією, акціями та знижками. Нині готелі борються за позитивну оцінку, так звані відгуки: користувач заходить на сайт, вибирає готель, що сподобався, пише коментар [14].

Не варто забувати, що соціальні мережі впливають на зовнішньоторговельну діяльність готелю. Гості, спілкуючись у Twitter, Facebook, мають унікальну можливість забронювати номер, використовуючи модернізовані гаджети [13].

Існують певні суб'єкти індустрії гостинності, які використовують технологію блокчейн. Потенційно вона здатна повністю змінити сферу туристичних послуг. Запит від мандрівників на надійність під час планування поїздок буде задоволений саме за допомогою блокчейна. Дані про купівлю квитків, бронювання номерів у готелях і роботі програм лояльності будуть існувати в одному цифровому просторі. Це допоможе всім сторонам, що працюють у сфері надання послуг у рамках однієї поїздки, орієнтуватися на фактичні відомості про клієнтів і передбачати їхні бажання.

Мережа Instagram надає можливість користувачеві, перебуваючи в певному місці, отримувати вигідні пропозиції і повідомлення у своєму акаунті. Таким чином, модель отримання лайків та підписок передбачає автоматичну можливість інформувати гостя [5].

Тому головним трендом для готелів, які просувають себе у соціальних мережах, стають розроблення і реалізація побудови унікальних стратегій присутності, що дає 
змогу готелю знати про своїх конкурентів. Наприклад, готелі часто використовують спеціальні модернізовані мобільні додатки в межах свого готелю для доступності та зручності, що надається клієнтові. Так, статистика показує, що в індустрії гостинності механізми забезпечення готельними послугами передбачають переважно розглянуту вище аналітику використання операцій в Інтернеті [2].

У цілому застосування в роботі платформ дає змогу значно зміцнити взаємовідносини з клієнтом (інформувати та керувати клієнтами в дорозі), продавати більше послуг і підвищувати їхню ціну; підвищувати якість послуг (смартфон як ключ від номеру, реєстрація в готелі через додаток, обмін сповіщеннями з персоналом готелю через додаток), поліпшувати емоційне сприйняття (відмітка, де побували, та сортування фото за відвідуваними місцями, нагадування, вказівки й інструкції в аеропорту, на вокзалі, порту і на борту судна); створювати нові можливості для охоплення клієнтів і розуміння (повідомлення, реклама, відгуки).

У міжнародній практиці індустрія гостинності продає технологію емодзі для оцінки сервісу готелю. Відповідні картинки градуються за шкалою. Таким чином, клієнту легше оцінити комфорт, рівень персоналу і сервісу в готелі [5].

Висновки. У цілому проведене дослідження дає змогу чітко зрозуміти, що для цифрової трансформації в Україні величезну роль має відігравати ініціатива держави, ніж бізнесу. Ця специфіка, зокрема, призводить до випереджаючого розвитку сервісних IT-технологій для населення, що зумовлює активний розвиток «цифрових держпослуг», якими користується мільйони осіб. Уже відбувається «виживання» компаній старого типу новітніми, які впроваджують нові технології, забезпечують взаємодію з клієнтом зі старту планування подорожі до моменту оплати готелів та квитків.

\section{Список використаних джерел:}

1. Алеєва В.А., Мочалова Ю.Д. Застосування сучасних інформаційних технологій в управлінні бізнесом у сфері туризму. Бізнес-освіта в економіці знань. 2018. № 3. С. 3-6.

2. Андреев А. Відвідувачі Нью-Йоркського готелю зможуть спілкуватися з персоналом за допомогою емодзи. Отель. 2015. № 40(400). URL: http://exhibition.pir.ru/digest/1028/ (дата звернення: 09.06.2021).

3. Герчикова Е.3., Спиридонова Е.П. Соціологічні аспекти трансформації сфери рекреації та туризму в умовах цифрової економіки. Вісник Саратовського держсавного сочіально-економічного університету. 2018. № 3(72). С. 185-189.

4. Данилова Н.Ф., Сараєва И.В. Глобальний цифровий простір: перспективи та перешкоди для економічного розвитку країн. Новини Саратовського університету. Серія «Економіка. Управління. Право». 2019. Т. 9. Вип. 1. С. 65-73.

5. Іванов В.В., Волов А.Б. Антикрізисний менеджмент у готельному бізнесі. Москва : Інфра-М, 2010. 189 c.

6. Індустрія гостинності: технологічні можливості для MCП. МНИАП : вебсайт. 2019. URL: http://xn--80aplem.xn--p1ai/analytics/Industria-gostepriimstva-tehnologiceskie-vozmoznosti-dlaMSP/ (дата звернення: 09.06.2021).

7. Клейман А.А., Бабанчикова О.А. Удосконалення технології продажів туристичного продукту на основі впровадження інноваційних технологій. Вісник Національної академії туризму. 2015. № 3(35). С. 20-26.

8. Кущевий Н.Б. Технології та інновації для модернізації підприємства громадського харчування. Актуальні проблеми економіки, управління та освіти у сфері рекреації та туризму : збірник наукових праць. Санкт-Петербург ; Москва, 2015. С. 56-62.

9. Кущевий Н.Б., Іванова М.А. Технологія залучення споживачів у спільне створення цінності в індустрії гостинності. Сучасний готельно-ресторанний бізнес: економіка і менеджмент : матеріали VI Міжнар. наук.-практ. конф. викладачів, докторантів, аспірантів і студентів. Сімферополь, 2020. С. 88-93.

10. Морозов М.А., Морозова Н.С. Нова парадигма розвитку туризму і індустрії гостинності в умовах цифрової економіки. Вісник Російського нового університету. Серія «Людина та суспільство». 2018. № 1. С. 135-141. 
11. Пивоварова М.А. Стратегії приваблення клієнтів в індустрії гостинності. Маркетинг в Росії та за кордоном. 2000. № 2. URL: https://stud-baza.ru/strategii-privlecheniya-klientov-vindustrii-gostepriimstva-referat-reklama (дата звернення: 09.06.2021).

12. Тищенко С.В. Теоретичні основи поняття індустрії гостинності. Інфраструктура ринку. 2021. № 55.

13. Шерстнева М. Я шукаю готелі: найшвидший засіб забронювати. Лайфххакер. 2012. URL: https://lifehacker.ru/2012/09/21/i-fi nd-oteli/ (дата звернення: 09.06.2021).

14. Five ways to harness AI for the hospitality experience of the future. Hospitality Technology : website. 2018. URL: https:/hospitalitytech.com/5-ways-harness-ai-hospitality-expe rience-future (дата звернення: 09.06.2021).

15. Negroponte N. Being Digital. New York : Alfred A. Knopf, 1995. 272 p.

\section{References:}

1. Aleieva V.A., Mochalova Yu.D. (2018) Zastosuvannia suchasnykh informatsiinykh tekhnolohii $\mathrm{v}$ upravlinni biznesom $\mathrm{v}$ sferi turyzmu [Application of modern information technologies in business management in the field of tourism]. Biznes-osvita v Ekonomitsi Znan [Business Education in the Knowledge Economy], no. 3, pp. 3-6.

2. Andreev A. (2015) Gosti N'yu-Yorkskogo otelya smogut obshchat'sya s personalom posredstvom emodzi [New York hotel guests will be able to communicate with staff using emoji]. Vestnik Otel' [Bulletin Hotel], no. 40. Available at: http://exhibition.pir.ru/digest/1028/ (accessed 09 June 2021).

3. Gerchikova E.Z., Spiridonova E.P. (2018) Sotsiologicheskie aspekty transformatsii sfery rekreatsii i turizma $\mathrm{v}$ usloviyakh tsifrovoy ekonomiki [Sociological aspects of the transformation of the recreation and tourism sphere in the digital economy]. Vestnik Saratovskogo Gosudarstvennogo Sotsial'no-ekonomicheskogo Universiteta [Bulletin of the Saratov State Social and Economic University], no. 3, pp. 185-189.

4. Danilova N.F., Saraeva I.V. (2019) Global'noe tsifrovoe prostranstvo: perspektivy i ugrozy dlya ekonomicheskogo razvitiya stran [Global digital space: prospects and threats for the economic development of countries]. Izvestiya Saratovskogo Universiteta. Seriya : Ekonomika. Upravlenie. Pravo [Bulletin of the Saratov University. Series: Economics. Management. Law], vol. 9, issue 1, pp. 65-73.

5. Ivanov V.V., Volov A.B. (2010) Antikrizisnyy menedzhment v gostinichnom biznese [Anti-crisis management in the hotel business]. Moscow: Infra-M.

6. Industriyagostepriimstva:tekhnologicheskievozmozhnostidlyaMSP [Hospitalityindustry:technological opportunities for SMEs] (2019). MNIAP (website). Available at: http://xn--80aplem.xn--p1 ai/ analytics/Industria-gostepriimstva-tehnologiceskie-vozmoznosti-dla-MSP/ (accessed 09 June 2021).

7. Kleyman A.A., Babanchikova O.A. (2015) Sovershenstvovanie tekhnologii prodazh turistskogo produkta na osnove vnedreniya innovatsionnykh tekhnologiy [Improving the technology of selling a tourist product through the introduction of innovative technologies]. Vestnik Natsionalnoy Akademii Turizma [Bulletin of the National Academy of Tourism], no. 3, pp. 20-26.

8. Kushchevyi N.B. (2015) Tekhnolohii ta innovatsii dlia modernizatsii pidpryiemstva hromadskoho kharchuvannia [Technologies and innovations for modernization of public catering enterprises]. Aktualni Problemy Ekonomiky, Upravlinnia ta Osvity u Sferi Rekreatsii ta Turyzmu [Current Problems of Economics, Management and Education in the Field of Recreation and Tourism]. St. Petersburg; Moscow, pp. 56-62.

9. Kushchevyi N.B., Ivanova M.A. (2020) Tekhnolohiia zaluchennia spozhyvachiv u spilne stvorennia tsinnosti v industrii hostynnosti [Technology of involving consumers in the common creation of value in the hospitality industry]. Proceedings of the Suchasnyi Hotelno-restorannyi Biznes: Ekonomika i Menedzhment: VI Mizhnarodna naukovo-praktychna konferentsiia vykladachiv, doktorantiv, aspirantiv i studentiv. Simferopol, pp. 88-93.

10. Morozov M.A., Morozova N.S. (2018) Novaya paradigma razvitiya turizma i industrii gostepriimstva $\mathrm{v}$ usloviyakh tsifrovoy ekonomiki [A new paradigm for the development of tourism and the hospitality industry in the digital economy]. Vestnik Rossiyskogo Novogo Universiteta. Seriya : Chelovek $i$ Obshchestvo [Bulletin of the Russian New University. Series: Man and Society], no. 1, pp. 135-141.

11. Pivovarova M.A. (2000) Strategii privlecheniya klientov v industrii gostepriimstva [Customer acquisition strategies in the hospitality industry]. Marketing $v$ Rossii i za Rubezhom [Journal of Marketing in Russia and Abroad], no. 2. Available at: https://stud-baza.ru/strategii-privlecheniya-klientov-v-industrii-gostepriimstva-referat-reklama (accessed 09 June 2021). 
12. Tyshchenko S.V. (2021) Teoretychni osnovy poniattia industrii hostynnosti [Theoretical foundations of the concept of the hospitality industry]. Infrastruktura Rynku [Market Infrastructure], no. 55 .

13. Sherstneva M. (2012) Ya ishchu oteli: samyy prostoy sposob zabronirovat' [I'm looking for hotels: the easiest way to book]. Layfkhaker (internet journal). Available at: https://ifehacker.ru/ 2012/09/21/i-fi nd-oteli/ (accessed 09 June 2021).

14. Five ways to harness AI for the hospitality experience of the future (2018). Hospitality Technology (website). Available at: https://hospitalitytech.com/5-ways-harness-ai-hospitality-experience-future (accessed 09 June 2021).

15. Negroponte N. (1995) Being Digital. New York: Alfred A. Knopf. 